\title{
A Case of Synchronous Double Primary Cancer in the Nasopharynx and Nasal Cavity Related with Epstein-Barr Virus
}

\author{
Sang Woo Seon ${ }^{1}$, Eunsang Lee ${ }^{1}$, Chang Gok Woo ${ }^{2}$, and Jae Yong Lee ${ }^{1}$ \\ ${ }^{1}$ Departments of Otorhinolaryngology-Head and Neck Surgery, ${ }^{2}$ Pathology, Soonchunhyang University College of Medicine, \\ Bucheon Hospital, Bucheon, Korea
}

\author{
Epstein-Barr Virus와 연관되어 발생한 비인두와 비강의 동시성 이중원발암 1 예 \\ 선상우 ${ }^{1} \cdot$ 이은상 $^{1} \cdot$ 우창곡 $^{2} \cdot$ 이재용 ${ }^{1}$ \\ 순천향대학교 의과대학 부천병원 이비인후-두경부외과학교실, ${ }^{1}$ 병리학교실 ${ }^{2}$
}

\author{
Received October 7, 2016 \\ Revised December 2, 2016 \\ Accepted December 5, 2016 \\ Address for correspondence \\ Jae Yong Lee, MD, PhD \\ Department of Otorhinolaryngology- \\ Head and Neck Surgery, \\ Soonchunhyang University \\ College of Medicine, \\ Bucheon Hospital, \\ 170 Jomaru-ro, Bucheon 14584, \\ Korea \\ Tel $+82-32-621-5448$ \\ Fax $+82-32-621-5016$ \\ E-mail jyent@schmc.ac.kr
}

\begin{abstract}
Multiple primary malignant neoplasms indicate an occurrence of two or more malignancies in a patient, and double primary cancers are the most common type. When the second primary cancer occurs simultaneously or within 6 months after the first primary cancer is diagnosed, it is called synchronous carcinoma. If the second primary cancer occurs after 6 months, it is defined as metachronous carcinoma. Recently, we experienced a patient who was diagnosed as double primary cancer in the nasopharynx and nasal cavity. The tumors occurred simultaneously and histopathological examinations revealed nasopharyngeal nonkeratinizing carcinoma in the right nasopharynx and extranodal NK/T-cell lymphoma in the left nasal cavity (inferior turbinate). In situ hybridization showed positivity for Epstein-Barr virus, which encoded early RNA in the neoplastic cells of both specimens. We present this rare disease entity with a review of the relevant literature and a survey of the clinical characteristics.
\end{abstract}

Korean J Otorhinolaryngol-Head Neck Surg 2018;61(4):217-22

Key Words Epstein-barr virus · Multiple primary neoplasms · Nasal cavity · Nasopharyngeal carcinoma $\cdot$ NK/T-cell lymphoma.

\section{서 론}

다발성 원발암은 2 개 이상의 다른 원발부위를 가지는 암을 뜻하며 그중 이중원발암은 다발성 원발암의 가장 흔한 종류이 다. 다발성 원발암은 암이 진단된 시간 차이에 따라 2가지로 나눌 수 있는데, 첫 번째 원발부위에서 암이 진단된 후 6개월 이내에 다른 원발부위에서 또 다른 암이 진단되는 경우를 동시 성 암(synchronous carcinoma)으로, 6개월 이후에 진단되는 경우를 이시성 암(metachronous carcinoma)으로 정의한다.1)

This is an Open Access article distributed under the terms of the Creative Commons Attribution Non-Commercial License (http://creativecommons.org/licenses/by-nc/4.0) which permits unrestricted non-commercial use, distribution, and reproduction in any medium, provided the original work is properly cited.
이중원발암은 1889년 Billroth와 von Winiwarter ${ }^{2}$ 에 의해 처음 보고되었고 1932년에는 Warren과 Gates ${ }^{3)}$ 가 이중원발 암에 대한 기준을 제시하였는데, 이는 지금까지도 적용되고 있 다. 그 기준은 첫째, 조직병리학적으로 암이 확실해야 하고, 둘째, 각각의 암은 반드시 정상 점막이나 상피에 의해 분리되 어 있으면서 점막하 또는 상피 내부로의 연결이 없어야 하며, 셋째, 두 번째 발생한 암이 첫 번째 암의 전이병변이어서는 안 된다는 것이다.

다발성 원발암의 발생빈도는 증가 추세이며 암 환자의 약 $10 \%$ 에서 최초 치료를 받은 지 10년 안에 또 다른 원발암이 발 생한다는 연구 결과도 있다. ${ }^{4}$ 하지만 본 증례와 같이 인접한 비인두와 비강에서 이중원발암이 발생한 경우는 상당히 드물 
며, ${ }^{5}$ 특히 Epstein-Barr virus(EBV)와 연관된 서로 다른 종류 의 동시성 이중원발암은 보고된 바 없기 때문에 문헌고찰과 함께 소개하고자 한다.
증 례

46세 여자가 2 3년 전부터 반복되는 코막힘과 화농성 비루
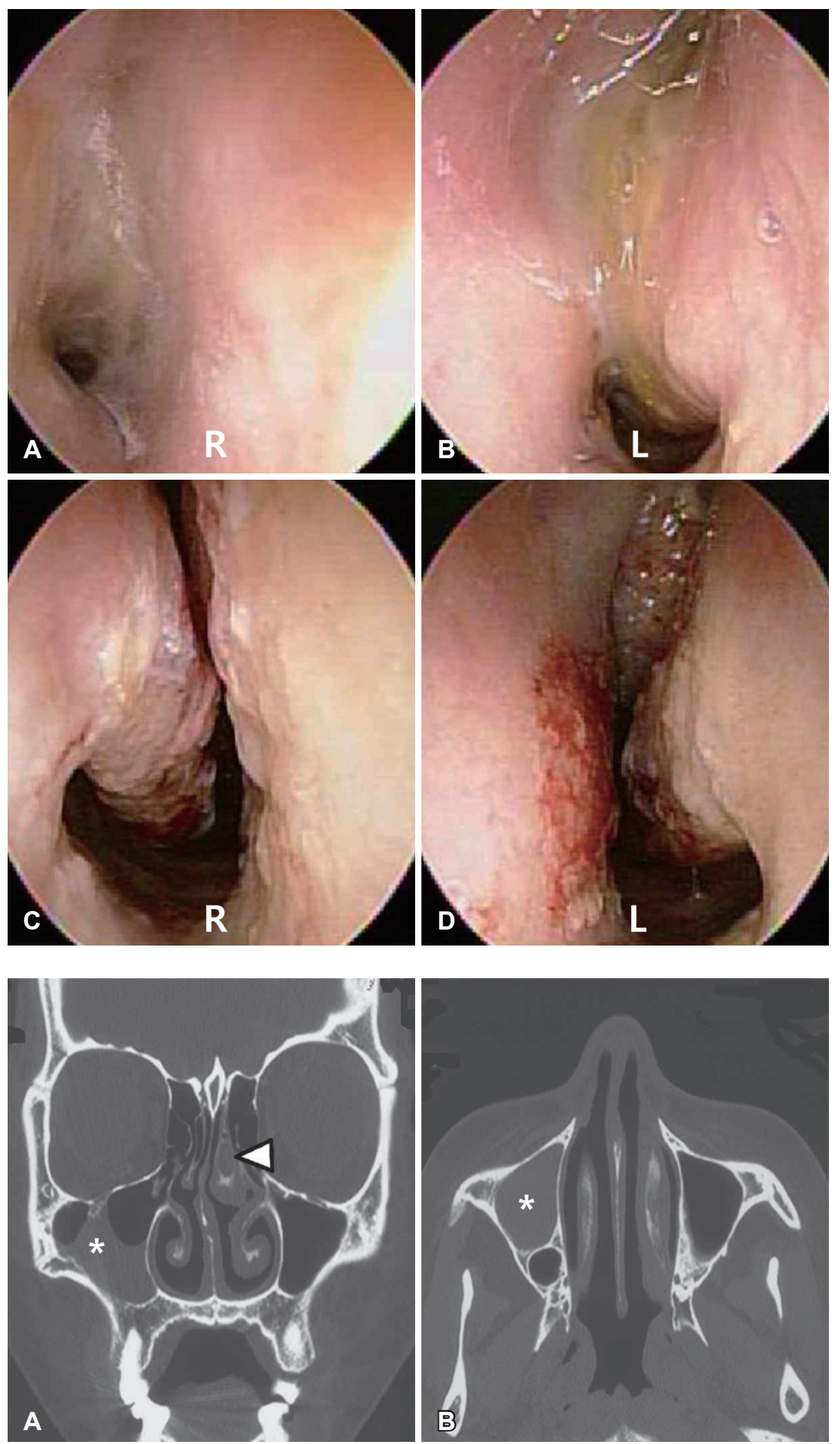

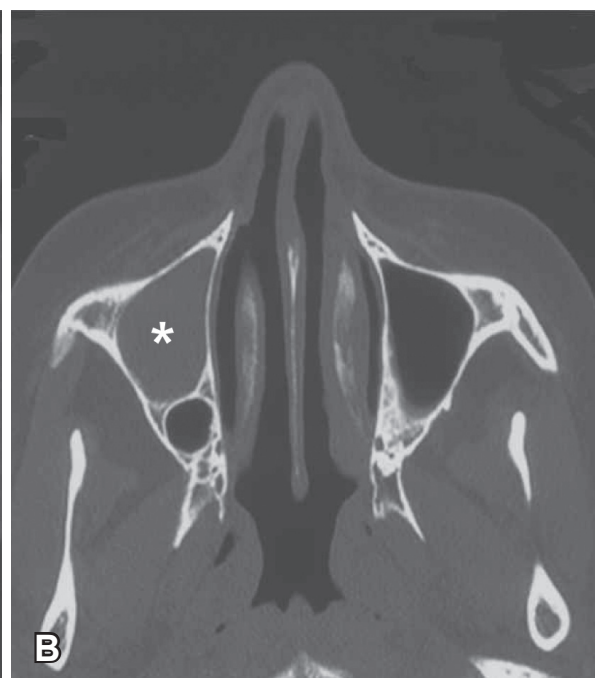

Fig. 1. Nasal endoscopy shows mucopurulent rhinorrhea in both nasal cavities (A and $B$ ). After removal of the discharge, erosive changes are noted on nasal mucosa of the septum and turbinates (C and D). R: right, L: left.
Fig. 2. Coronal (A) and axial (B) computed tomography scans taken at the local clinic demonstrate mucosal thickening in the right maxillary sinus $(*)$ and infected concha bullosa (arrowhead) of the left middle turbinate. Other sinuses, both nasal cavities, and nasopharynx show no specific findings. 
를 주소로 내원하였다. 증상은 2 3주 전부터 악화되었고, 두통 과 코골이 등도 호소하였으나, 특별한 내과적 병력은 없었다.

비내시경 검사에서 양측 비강을 채우고 있는 화농성 분비물 이 관찰되었으며(Fig. $1 \mathrm{~A}$ and $\mathrm{B}$ ), 분비물을 제거한 후에는 비강 점막의 전반적인 미란성 변화를 확인할 수 있었다(Fig. $1 \mathrm{C}$ and D). 내원 2주 전 개인병원에서 시행한 부비동 전산화 단층촬영에서는 우측 상악동의 경미한 점막 비후와 좌측 중 비갑개의 함기화가 관찰되었으며 양측 비강 및 비인두에 이상 소견은 보이지 않았다(Fig. 2).

화농성 분비물에 대한 세균배양검사 결과 메티실린 내성 황 색포도상구균(methicillin resistant Staphylococcus aureus) 이 검출되었고, 재발성 급성 비부비동염에 준하여 적절한 경 구 항생제를 투여하면서 1주일에 2회 빈도로 추적관찰하였 다. 2주간의 외래 처치와 약물 치료 후 환자의 주관적 증상 은 많이 완화되었고 비루의 양이 현저히 감소하였으며 비강 점
막 상태도 호전된 것을 확인할 수 있었다(Fig. 3). 영상검사에 서 부비동염이 심하지 않았고 주관적 증상 및 비내시경 소견이 호전되어 즉각적인 수술은 불필요할 것으로 생각되었으며 환 자도 수술을 원하지 않아 2 3달 간격으로 추적관찰하기로 하였다.

2달 후 외래에 방문하였을 때 특이 소견은 없었으나 직장 문 제로 5 개월간 추적관찰이 중단되었고 코막힘이 악화되어 다 시 내원하였다. 비내시경에서 우측 이관융기(torus tubarius) 상방의 비인두에 폴립양 병변이 관찰되었고(Fig. 4A) 좌측 하비갑개 후방으로 점막 표면에 괴사를 보이는 종양성 병변 이 확인되어(Fig. 4B) 부비동 전산화단층촬영과 자기공명영 상을 시행하였다. 양측 상악동과 좌측 사골동에 혼탁을 보였 고, 좌측 하비갑개 부위에 균일하지 않은 저음영의 종양성 병 변이 관찰되며, 우측 비인두 연부조직에서도 종양을 의심할 수 있는 소견을 보였다(Fig. 5).

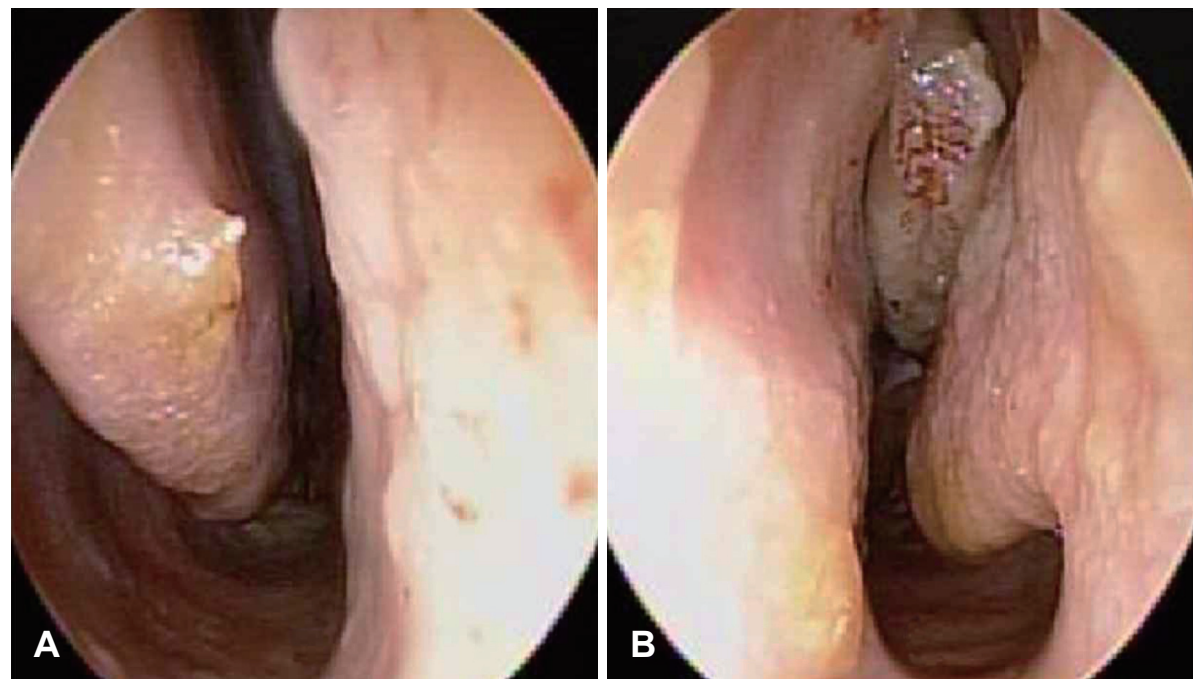

Fig. 3. After two weeks of medical management, nasal endoscopy shows disappearance of mucopurulent rhinorrhea and improvement of mucosal conditions of right $(A)$ and left (B) nasal cavities.

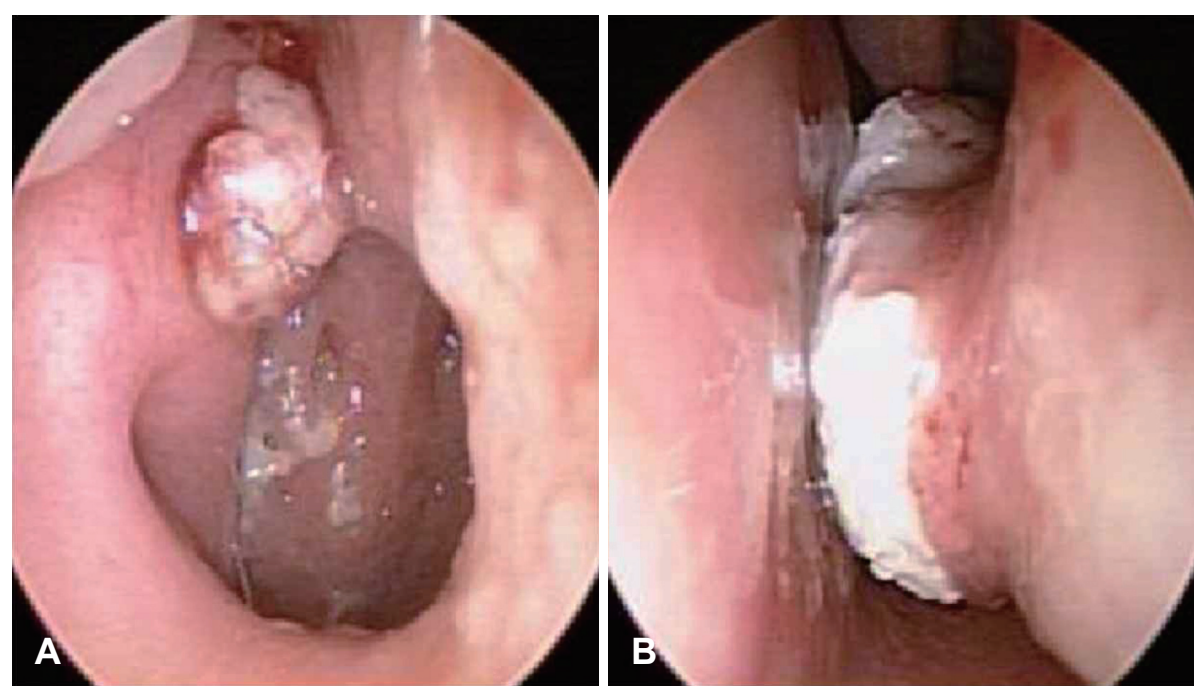

Fig. 4. After five months from the last follow-up, nasal endoscopy reveals polypoid mass in upper portion of the right torus tubarius $(A)$ and ulcerative surfaced mass at posterior portion of the left inferior turbinate (B). 
정확한 진단을 위하여 전신마취하에 우측 비인두와 좌측 하비갑개 후방의 병변에 대한 내시경적 절제 및 생검을 시행 하였다. 일반 염색과 면역조직화학염색 결과 우측 비인두 종
양은 cytokeratin 5/6와 p63에 양성을 보여 비인두 비각질화암 (nasopharyngeal nonkeratinizing carcinoma)(Fig. 6A, B, and C)으로, 좌측 하비갑개 후방의 괴사성 병변은 CD3와 CD56
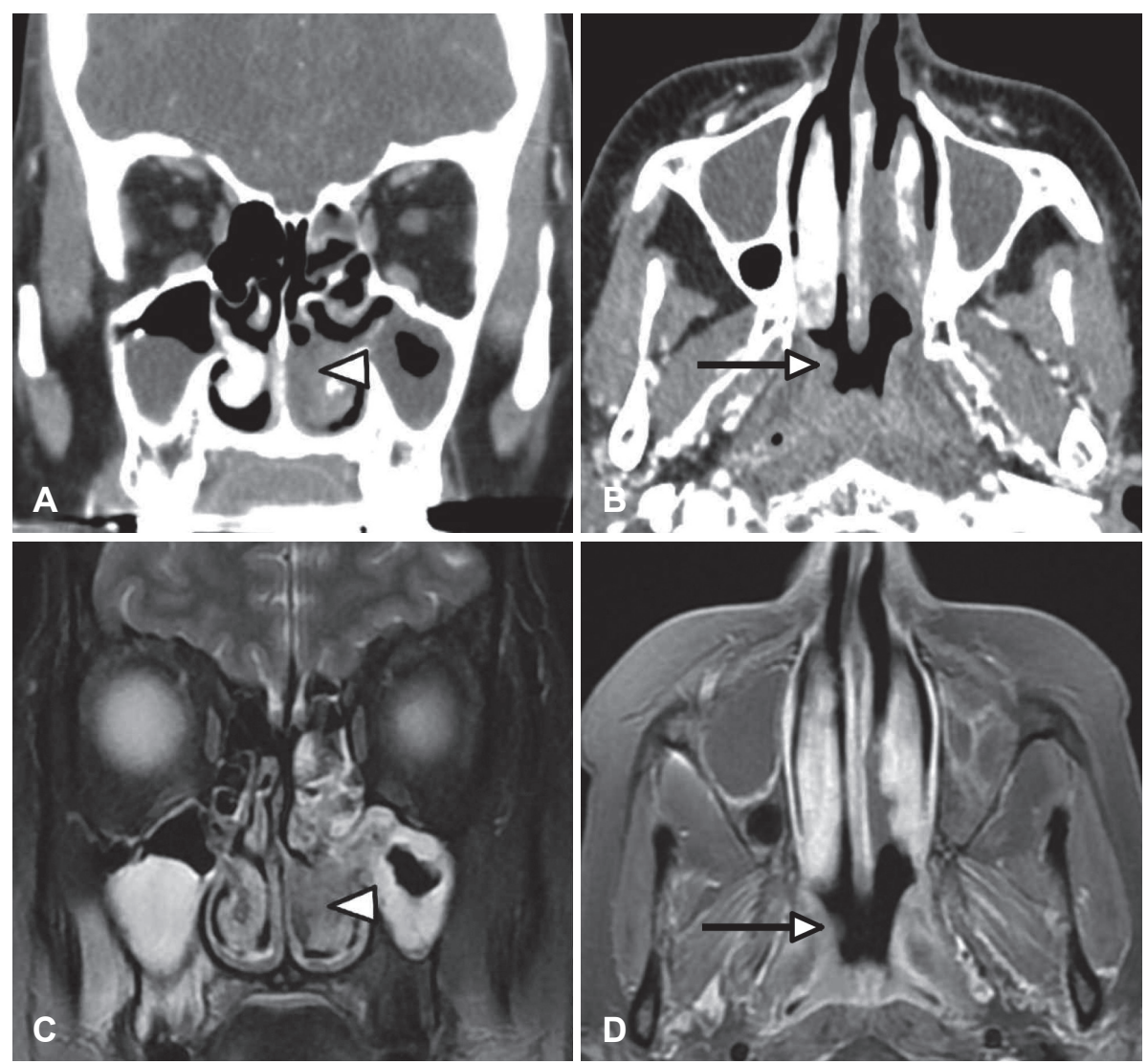

Fig. 5. Contrast-enhanced coronal (A) and axial (B) computed tomography scans show hypodense mass in the left inferior turbinate (arrowhead) and protruding mass in the right nasopharynx (arrow). Coronal T2-weighted (C) and axial T1-weighted (D) magnetic resonance images show similar findings with those of computed tomography (arrowhead and arrow).
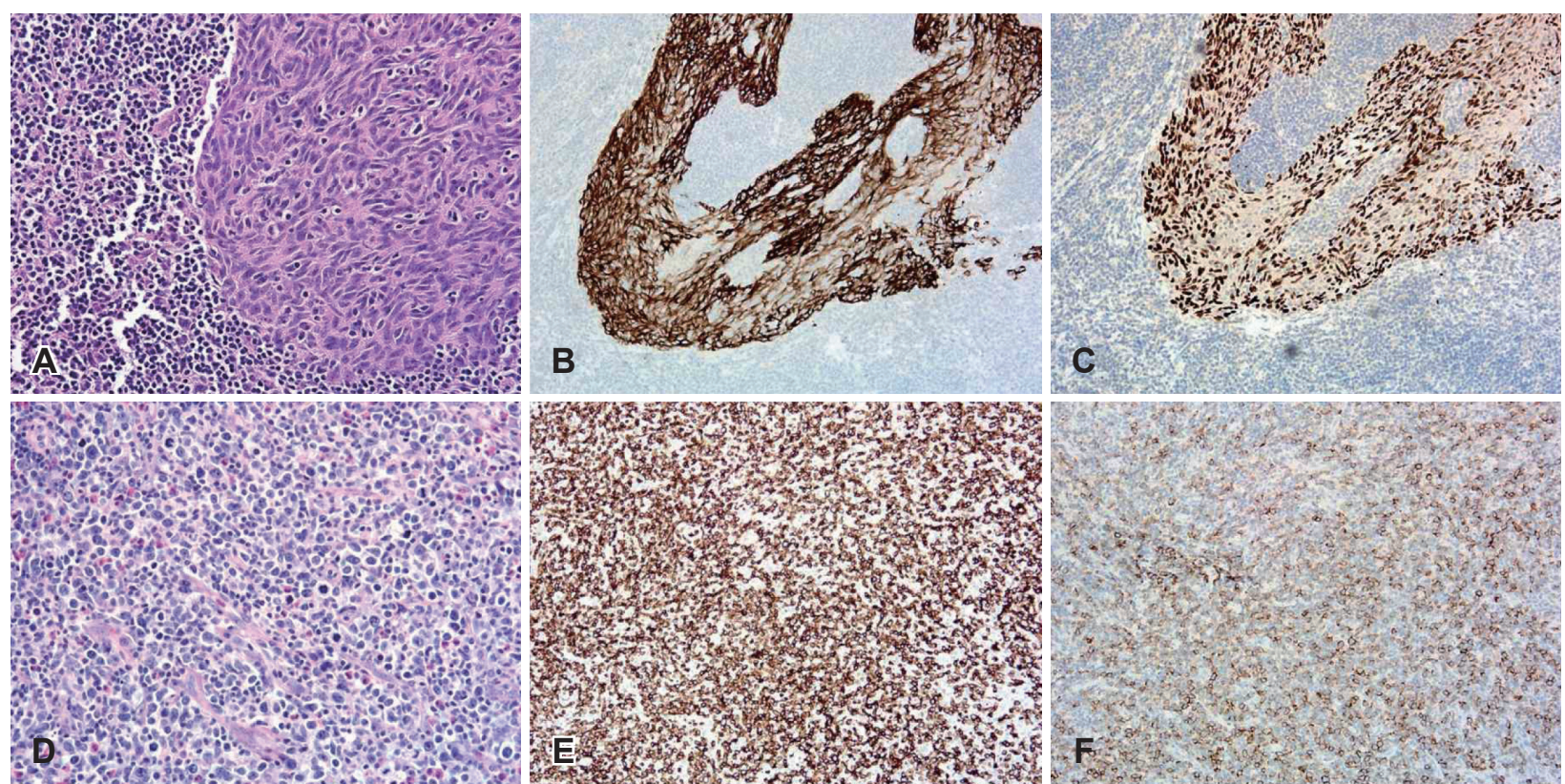

Fig. 6. Nasopharyngeal nonkeratinizing carcinoma has syncytial-appearing oval to spindle cells with crowded or overlapping nuclei, eosinophilc cytoplasm, and lymphocyte-rich stroma (A, H\&E stain, $\times 400)$. Immunohistochemistry shows positive reaction to cytokeratin $5 / 6$ $(B, \times 200)$ and p63 (C, × 200). Extranodal NK/T-cell lymphoma shows irregularly folded nuclei with pale to clear cytoplasm. Mitotic figures are easily found (D, H\&E stain, $\times 400)$. Tumor cells demonstrate positivity to CD3 $(E, \times 200)$ and CD56 $(F, \times 200)$ on immunohistochemistry. 
에 양성을 보여 결절 외 NK/T 세포 림프종(extranodal NK/ T-cell lymphoma)(Fig. 6D, E, and F)으로 판명되었다. 이와 같이 환자는 비인두 및 비강의 조직병리검사 소견이 다른 이 중원발암 진단을 받았고, 또한 각각의 조직을 이용하여 시행한 $\mathrm{EBV}$ encoded early RNA(EBER)의 in situ hybridization 검 사상 모두 양성을 보였다. 양전자 전산화단층촬영, 경부 전산 화단층촬영에서 타 기관으로의 전이는 발견되지 않았다.

혈액종양내과와 방사선종양학과와의 협진하에 항암화학 요법 및 방사선치료를 시행한 후 6개월이 경과한 현재 완전관 해(complete remission)를 보이며 주기적인 경과관찰 중이다.

\section{고 찰}

1932년 Warren과 Gates ${ }^{3}$ 에 의해 이중원발암 환자가 처음 으로 소개된 후 방대한 양의 증례들이 보고되었고 그 발생빈 도도 증가하고 있다. ${ }^{6,7)}$ 지금까지의 보고들이 대부분 서로 다 른 조직 또는 기관에서 발생하였으나, 양측 상악동 또는 비인 두와 비강에서 발생한 이중원발암의 증례들도 발표된 바 있 다. ${ }^{5,8,9)}$ 하지만 대부분 동일 암종이면서 5 18년이 경과한 후에 두 번째 암이 발생한 이시성 암종이었고, 이와는 다르게 본 증 례에서는 인접한 동일 점막 조직인 비인두 및 비강에서 두 가 지 종류의 암종이 동시에 발생하였는데 이는 이전에 소개된 적 이 없는 극히 드문 경우이다. 또한 각각의 조직을 이용한 $\mathrm{EBER}$ 의 in situ hybridization 검사에서 양성 소견을 보였는데, EBV 와 연관되어 발생한 동시성 이중원발암의 증례 역시 찾아볼 수 없었다.

비인두암은 비인두에서 유래하는 상피세포성 악성종양으 로서 $\mathrm{EBV}$ 의 잠복감염과 연관성을 갖는다. ${ }^{10)}$ 결절 외 $\mathrm{NK} / \mathrm{T}$ 세포 림프종은 성숙 $\mathrm{NK}$ 세포로부터 유래하는 악성종양으로 극동아시아와 남미에서 발생빈도가 높으며 이 질환 역시 $\mathrm{EBV}$ 의 잠복감염과 연관이 있다. ${ }^{11)} \mathrm{EBV}$ 가 암을 발생시키는 기전 은 아직 명확히 밝혀지지 않았지만 버킷 림프종(Burkitt’s lymphoma), 호지킨 림프종(Hodgkin's lymphoma), 비호지킨 림 프종(non-Hodgkin's lymphoma), 위암, AIDS 연관 림프종과 같은 다양한 암의 발생에 작용하는 것으로 보고되고 있다. ${ }^{12)}$

본 증례에서는 특별한 내과적 과거력이 없는 환자가 반복 되는 비부비동 염증 증상을 주소로 내원하였고, 내시경 검사 에서 명확한 종양성 병변을 발견할 수 없었으며, 약물 치료 후 주관적인 증상과 객관적인 점막 상태의 호전을 보였기 때문 에 종양, 특히 이중원발암의 발생을 예측하기는 어려웠다. 그 리고 특이 소견이 없었던 마지막 추적관찰로부터 5개월 후에 비인두와 하비갑개의 병변이 발견되었기 때문에 동시성 이중 원발암에 해당된다고 할 수 있겠다. 이중원발암과 관련된 한
연구에서는 식도, 난소, 후두, 인두 그리고 구강 등이 이중원 발암 중 두 번째 원발암이 호발하는 조직이라는 연구 결과가 있다. ${ }^{13)}$ 하지만 언급한 바와 같이 서로 다른 조직이나 기관이 아닌 인접한 비점막 조직에서 두 종류의 동시성 이중원발암이 발생한 사례는 보고된 바 없으며, 또한 $\mathrm{EBER}$ 에 대한 검사에 서 양성을 보여 이중원발암 발생에 $\mathrm{EBV}$ 가 관여하였을 것으 로 판단할 수 있었다.

이중원발암의 치료는 내시경이나 영상학적 검사를 통한 암 종의 정확한 위치와 범위의 파악, 그리고 생검을 통한 조직병 리학적 진단이 우선되어야 한다. 이후 수술적 절제와 더불어 방 사선치료 및 항암화학요법 등의 부가적 치료를 진행한다. ${ }^{14,15)}$ 본 증례에서는 절제생검 결과 비인두암과 결절 외 $\mathrm{NK} / \mathrm{T}$ 세포 림프종으로 판명되어 방사선치료와 함께 cisplatin을 기반으로 한 항암화학요법을 병행해서 시행하였고, 현재 주기적인 외래 추적관찰 중이다.

매우 드물기는 하지만 영상학적인 검사 결과에 비해서 또는 비강의 급성 염증으로 보기에는 전반적인 비점막 상태가 상당 히 불량한 환자에서 최초 진료로부터 약 6 12개월 이후에 림 프종과 같은 악성종양이 발현되는 경우를 몇 차례 경험한 바 있다. 따라서 이와 유사한 진찰 소견을 보이는 환자에서는 주 기적인 외래 추적관찰과 비내시경을 통한 검사가 반드시 필 요하다는 점을 염두에 두어야 하겠다.

\section{Acknowledgments}

This study was supported by the Soonchunhyang University Research Fund.

\section{REFERENCES}

1) Moertel CG, Dockerty MB, Baggenstoss AH. Multiple primary malignant neoplasms. II. Tumors of different tissues or organs. Cancer 1961;14(2):231-7.

2) Billroth T, von Winiwarter A. General surgical pathology and therapeutics in 51 vorlesungen: a textbook for students and physicians in fifty-one lectures. 14th ed. Berlin: G Rerimer;1889.

3) Warren $S$, Gates O. Multiple primary malignant tumors. A survey of the literature and a statistical study. Am J Cancer 1932;16:1358-414.

4) Tsukuma H, Fujimoto I, Hanai A, Hiyama T, Kitagawa T, Kinoshita $\mathrm{N}$. Incidence of second primary cancers in Osaka residents, Japan, with special reference to cumulative and relative risks. Jpn J Cancer Res 1994;85(4):339-45.

5) Chen CL, Hsu MM. Second primary epithelial malignancy of nasopharynx and nasal cavity after successful curative radiation therapy of nasopharyngeal carcinoma. Hum Pathol 2000;31(2):22732.

6) Mariotto AB, Rowland JH, Ries LA, Scoppa S, Feuer EJ. Multiple cancer prevalence: a growing challenge in long-term survivorship. Cancer Epidemiol Biomarkers Prev 2007;16(3):566-71.

7) Freeman HJ. Triple metachronous colon cancer. World J Gastroenterol 2013;19(27):4443-4.

8) Lee HS, Lee BJ, Kim YW, Roh HJ. Two cases of metachronous squamous cell carcinoma involving both maxillary sinuses. Korean J Otolaryngol-Head Neck Surg 2005;48(2):260-2. 
9) Ichimura K, Nozue M, Hoshino T, Yano J. Bilateral primary malignant neoplasms of the maxillary sinus: report of a case and statistical analysis of the reports in Japan. Laryngoscope 1981;91(5):804-10.

10) Young LS, Rickinson AB. Epstein-Barr virus: 40 years on. Nat Rev Cancer 2004;4(10):757-68.

11) Hung LY, Chang PH, Lee TJ, Hsu YP, Chen YW, Fu CH, et al. Extranodal natural killer/T-cell lymphoma, nasal type: clinical and computed tomography findings in the head and neck region. Laryngoscope 2012;122(12):2632-9.

12) Kieff ED, Rickinson AB. Epstein-Barr virus and its replication. In: Knipe DM, Howley PM, editors. Fields virology. 5th ed. Philadelphia:
Lippincott Williams and Wilkins;2007. p.2603-54.

13) Tabuchi T, Ito Y, Ioka A, Miyashiro I, Tsukuma H. Incidence of metachronous second primary cancers in Osaka, Japan: update of analyses using population-based cancer registry data. Cancer Sci 2012;103(6):1111-20.

14) Blanchard P, Lee A, Marguet S, Leclercq J, Ng WT, Ma J, et al. Chemotherapy and radiotherapy in nasopharyngeal carcinoma: an update of the MAC-NPC meta-analysis. Lancet Oncol 2015;16(6): 645-55.

15) Razak AR, Siu LL, Liu FF, Ito E, O'Sullivan B, Chan K. Nasopharyngeal carcinoma: the next challenges. Eur J Cancer 2010;46(11):1967-78. 